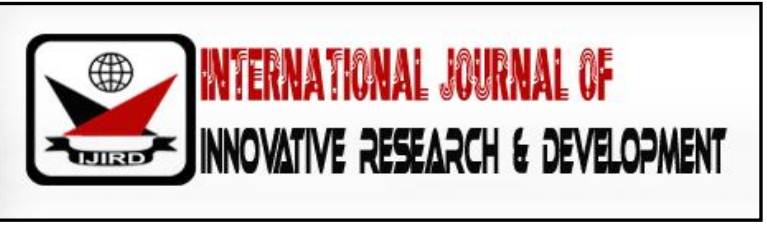

ISSN 2278 - 0211 (Online)

\title{
Capsicum Frutescens Exhibits Tachyphylaxis In Gastric Acid Secretion
}

Dr. Akwaras Nndunno Asheku
Senior Registrar, Department of Family Medicine, Federal Medical Centre, Nigeria
Dr. Julie Ibu
Chief Inspector, National Youth Service Corps, Benue State Secretariat, Nigeria
Christian Onahinon
Masters Student, Department of Physiology, College of Health Sciences, Benue State University, Nigeria
Dr. Emmanuel Eru
Lecturer, Department of Physiology, Benue State University, Nigeria
Dr. Austin Adugba
Lecturer, Department of Physiology Benue State University, Nigeria
Linus Saalu
Lecturer, Benue State University, Nigeria
John Ibu
Professor of Physiology, Benue State University, Nigeria

\begin{abstract}
:
Capsicum frutescens has been found to increase gastric acid secretion (Ibu et al., 1993). Capsicum frutescens is a species of pepper that is widely used as spice both in Nigeria and elsewhere (Ibu et al., 1993). There is paucity of literature on its action on gastric acid secretion. This prompted the present study. 40 male and female albino Wistar rats weighing between 200-300 g were randomly placed in five groups having 8 rats per group. The method of Alnaqueeb (1996) was used to prepare aqueous extract of Capsicum frutescens which was administered through a gastric fistula created at the fundus. 10\%, 20\%, of LD 50 and supramaximal doses of $10 \mathrm{mg}, 20 \mathrm{mg}, 30 \mathrm{mg}, 40 \mathrm{mg}, 50 \mathrm{mg}, 60 \mathrm{mg}, 70 \mathrm{mg}$ and $80 \mathrm{mg}$ of the aqueous extract were administered. Ghosh and Schild 1958 method as modified by Ibu (1987) was employed to measure gastric acid secretion. The result of gastric acid secretion on administration of $10 \%$ of $\mathrm{LD}_{50}$ dose in $\mathrm{mmol} / \mathrm{L} /$ hour for basal acid output (BAO) was $16.2 \pm$ 0.01 and $18.1 \pm 0.04,18.6 \pm 0.03,18.6 \pm 0.10,17.4 \pm 0.9,16.02 \pm 0.9$ and $15.36 \pm 0.16$ at 70, 80, 90, 100, 110 and 120 minutes respectively. It was observed that gastric acid secretion increased and rose to a maximum between 50 and 70 minutes. It then began to decline in acid secretion between 80 and 120 minutes. This decline is due to a phenomenon called tachyphylaxis.
\end{abstract}

Keywords: Gastric acid secretion, capsicum frutescens, tachyphylaxis

\section{Introduction}

Capsicum specie are edible spices that contain capsaicin, a natural vanilloid compound responsible for their pungency and hot sensation associated with the taste of these peppers. Gastric acid is secreted by parietal cells and concentrated in the fundic area of the stomach. Early scientific queries on gastric acid secretion led to the carbonic anhydrase theory of gastric acid promulgated by Horace Davenport in 1943 (Ibu,1987). Ibu, (1987) elucidated that the mechanism of gastric acid secretion occurs at both the basolateral surface of the parietal cell and the apical/secretory surface of the canalicular membrane. This was corroborated in a review by Samuelson and Hinkle, 2003. They described the importance of the $\mathrm{H}^{+} / \mathrm{K}^{+}$ ATPase, also referred to as the 'proton pump' which is magnesium dependent and is located in the canalicular membrane (Ibu, 1987, Samuelson and Hinkle, 2003).

Ibu et al., 1993 in a review, discussed various hypothesis that have been propounded to explain receptors involved in gastric acid secretion. The review stated that the hypothesis that is most accepted are the one receptor (histamine) hypothesis and the three-receptor hypothesis. The one receptor hypothesis suggests that histamine is the final common mediator of acid secretion and that only $\mathrm{H}_{2}$ receptors found on the parietal cell are concerned with gastric acid secretion in the stomach. Therefore, acetylcholine and gastrin first act first to release of histamine. Subsequently the released histamine through the $\mathrm{H}_{2}$ 
receptor activation leads to secretion of gastric acid by the parietal cells. In the three-receptor hypothesis, each of acetylcholine, histamine and gastrin acts on its own specific receptor to cause acid secretion, but synergistic interaction occur between the mediator and histamine occupies a central position in the relationship (Ibu, 1993).

Capsaicin binds on transient receptor potential vanilloid 1 (TRPV1) (Green, 1996). Other naturally occurring vanilloids that are TRPV1 agonists include piperine, resiniferatoxin, zingerone and gingerol (Szallasi and Blumberg, 1999; Dedov et al., 2002). They contain the vanillyl group 4- hydroxyl-3-methoxy benzyl (Szallasi and Blumberg, 1999; Dedov et al., 2002). TRPV1 is mainly expressed in dorsal root ganglia, trigeminal ganglia, in small sensory C fibers and some alpha delta fibers. TRPV1 is also found in brain, spinal cord, bowel, liver, spleen, lung, bladder, kidney and testis (Gunthorpe et al., 2002). It is a member of the acid sensing system and is involved in homeostasis of gastric acid secretion through activation of the sensory nerves and release of calcitonin gene related peptide (CGRP) (Holzer, 2006, 2007a, 2007 b). TRPV1 can be activated by histamine through phosphorylation by protein kinase C (PKC) (Jara- Oseguera, 2008).

The different effects of capsaicin have been described as involving excitation, a sensory-blocking effect, long-term selective neurotoxic impairment and irreversible cell destruction (McNamara et al., 2005).

\section{Materials and Methods}

Capsicum frutescens were bought from the local market (Wadata Market) in Makurdi, Benue State, Nigeria. The pepper was identified by a taxonomist in the department of Botany, Faculty of Sciences of Benue State University, Nigeria and a specimen voucher deposited in their herbarium.

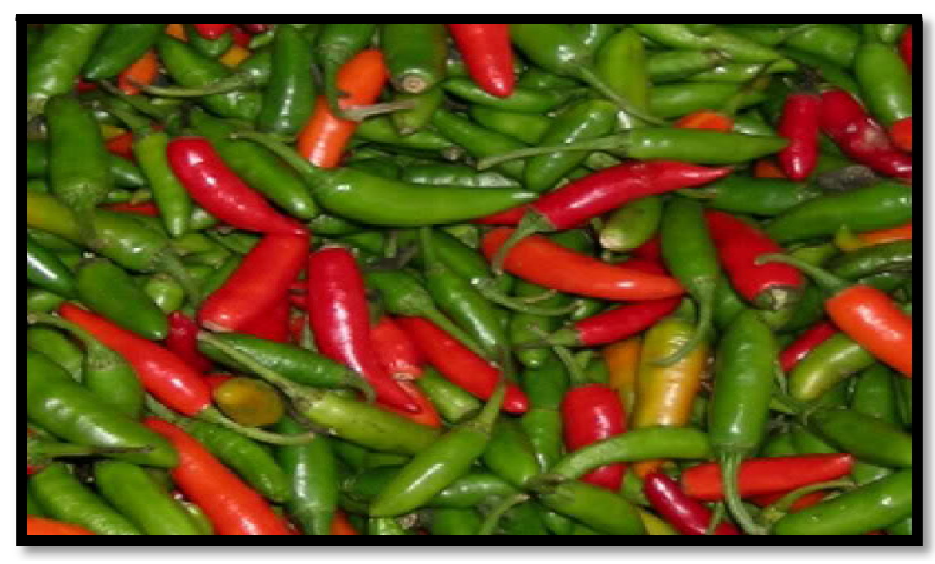

Figure 1: Specimen of Capsicum Frutescens Fruit

\subsection{Drugs and Chemicals}

Analytical grade Sodium hydroxide $(\mathrm{NaOH})$, Sodium Chloride $(\mathrm{NaCl})$ and phenolphthalein made by May and Baker (Dagenham, England) and urethrane made by Sigma Chemical Co. (Poole, UK).

\subsection{Animals}

Forty Albino Wistar rats weighing 200-300g of both sexes were obtained from the animal house of the College of Health Sciences, Benue State University, Makurdi and nursed under the same conditions in the animal house research laboratory. They were subjected to a 12-hour light and dark photic cycle. And fed on normal rat chow (Pfizer Limited, Kaduna, Nigeria) and given water ad libitum. Permission for the use of the animals was obtained from the Animal Ethics Committee of Benue State University Makurdi, Nigeria.

\subsection{Preparation of the Extract}

The aqueous extract preparation was being modified following the method of Alnaqeeb et al., (1996). 50g (Wt 1) of the fresh fruit was thoroughly washed and placed in clean beakers (Pyrex, $500 \mathrm{ml}$ ). It was homogenized in 75ml (V1) of cold sterile $0.9 \%$ saline in the presence of some crushed ice using an electric blender. The homogenous mixture was filtered with What man no1 filter paper and centrifuged at $2000 \mathrm{rev} / \mathrm{min}$ for 10 minutes and the clear supernatant was collected and volume noted (V2). The volume of the wet residue was noted as Wt 2. The volume of the supernatant was subtracted from the volume of the cold saline used in homogenization (V1 - V2) or V3 which was noted as Wt 3. The yield of each of the three preparations was used to determine the stock concentration.

stock concentration $=\mathrm{Wt} 1-(\mathrm{Wt} 2+\mathrm{Wt} 3) \div \mathrm{V} 2$

[ yield $=\mathrm{Wt} 1-(\mathrm{Wt} 2-\mathrm{Wt} 3)]$

The above formula was used to calculate the stock concentration of each which was then stored in refrigerator until used. The required amount was administered in $\mathrm{mg} /$ 100-gram body weight of each animal. 
$50 \mathrm{~g}$ of Capsicum frutescens contains $0.206 \pm 0.02 \mathrm{~g}$ of capsaicin (Ekwere et al., 2016). Oral LD 50 values of Capsaicin are $161.2 \mathrm{mg} / \mathrm{kg}$ (16.12 mg/ $100 \mathrm{~g}$ body weight) and $148.1 \mathrm{mg} / \mathrm{kg}$ (14.81 mg/ $100 \mathrm{~g}$ body weight) for male and female rats respectively ( Saito et al., 1996).

The above information from literature was used to determine the dose of capsicum extract that will be administered.

\section{Animal Grouping and Experimental Design} follows:

40 Wistar rats weighing between 200 - 300 grams were randomly assigned to five groups consisting of 8 each as

- Group 1- Control group for Capsicum frutescens which were administered normal saline.

- Group 2- were administered 10\% LD 50 of Capsicum frutescens.

- Group 3- were administered $20 \% \mathrm{LD}_{50}$ of Capsicum frutescens.

- Group 4- Control group for successive supramaximal doses of Capsicum frutescens which were administered normal saline.

- Group 5 - were administered successive supramaximal doses of Capsicum frutescens of 10mg, 20mg, 30mg, 40mg, 50mg, 60mg, $70 \mathrm{mg}$ and 80mg.

\section{Experimental Protocol}

After a 12 hour fast, each animal was anaesthetized with $25 \%$ Ethyl Carbonate (urethane) at a dose of $0.6 \mathrm{ml} / 100 \mathrm{~g}$ body weight intraperitoneally.

Tracheostomy was performed. A naso gastric tube was passed. A duodenostomy was performed and normal saline was used as gastric lavage to wash out the debris from the stomach until clear effluent was obtained. A duodeno gastric canula was passed and ligated insitu for subsequent collection of gastric acid secretion. 10 minutes aliquot samples were collected from the duodenal canula. A gastric fistula was created in the fundus with insertion of a 2-way canula to allow the administration of the extract. The aliquots were each titrated to a phenolphthalein end point using $0.01 \mathrm{M} \mathrm{NaOH}$ and the acid output or concentration is calculated as described by Ibu (1986), Ibu and Ebieme (1993) as follows:

Where Normality = Molarity

$\mathrm{MA} \mathrm{VA}=\mathrm{MB}$ VB

$\mathrm{MA}=\quad \mathrm{MB} \mathrm{VB} \div \mathrm{VA}$

Where,

$\mathrm{MB}=$ Molarity of base known $(0.01 \mathrm{~N})=10 \mathrm{mMol}$

$\mathrm{VB}=$ Volume of base known (titrate of $\mathrm{NaOH}$ ) used

$\mathrm{VA}=$ Volume of acid (effluent volume) $=10 \mathrm{ml}$

Substituting for $\mathrm{MB}$ and VA

$\mathrm{MA}=10 \times \mathrm{VB} \div 10$

Therefore $\mathrm{MA}=\mathrm{VB}$

Acid output $/ 10$ minutes $=\mathrm{VB} \mathrm{mMol} / \mathrm{L} / 10 \mathrm{mins}$

Acid output per hour = VB x $6 \mathrm{mMol} / \mathrm{L} /$ hour (Ibu, 1987).

The results were analysed for graphics and statistics using SPSS version 23. Statistical differences were accepted at $95 \%$ Confidence limit when $\mathrm{P} \varangle 0.05$.

\section{Results}

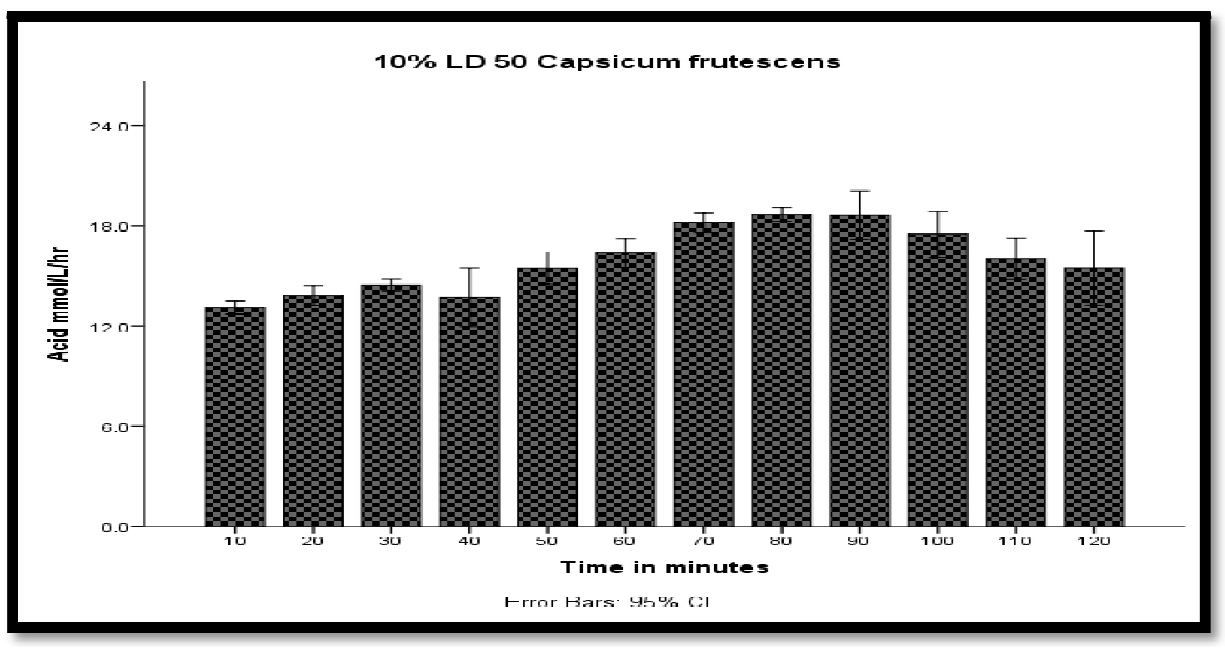

Figure 2 
Figure 2 shows the result following the administration of $10 \%$ of $\mathrm{LD}_{50}$. The acid produced increased steadily until it reached a plateau between 70 and 90 minutes. After that acid secretory response decreased between 100 and 120 minutes. This decline in acid secretory response is called tachyphylaxis.

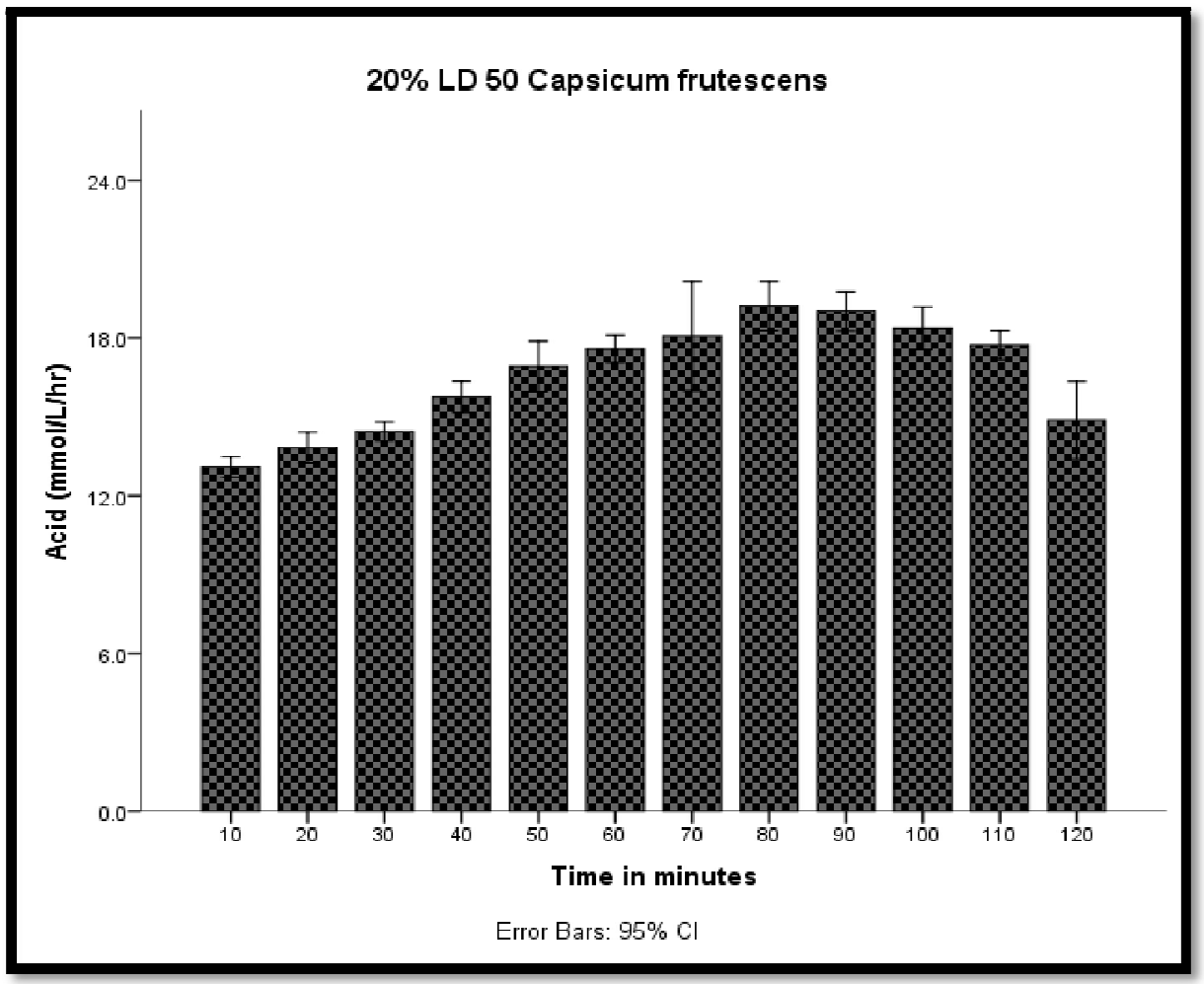

Figure 3

Figure 3- A graph depicting the effect of administering a dose of $20 \%$ of $\mathrm{LD}_{50}$ of Capsicum frutescens extract. A peak response is seen between 80 and 90 minutes. A decline in acid secretory response at 100, 110 and 120 minutes is also observed denoting tachyphylaxis.

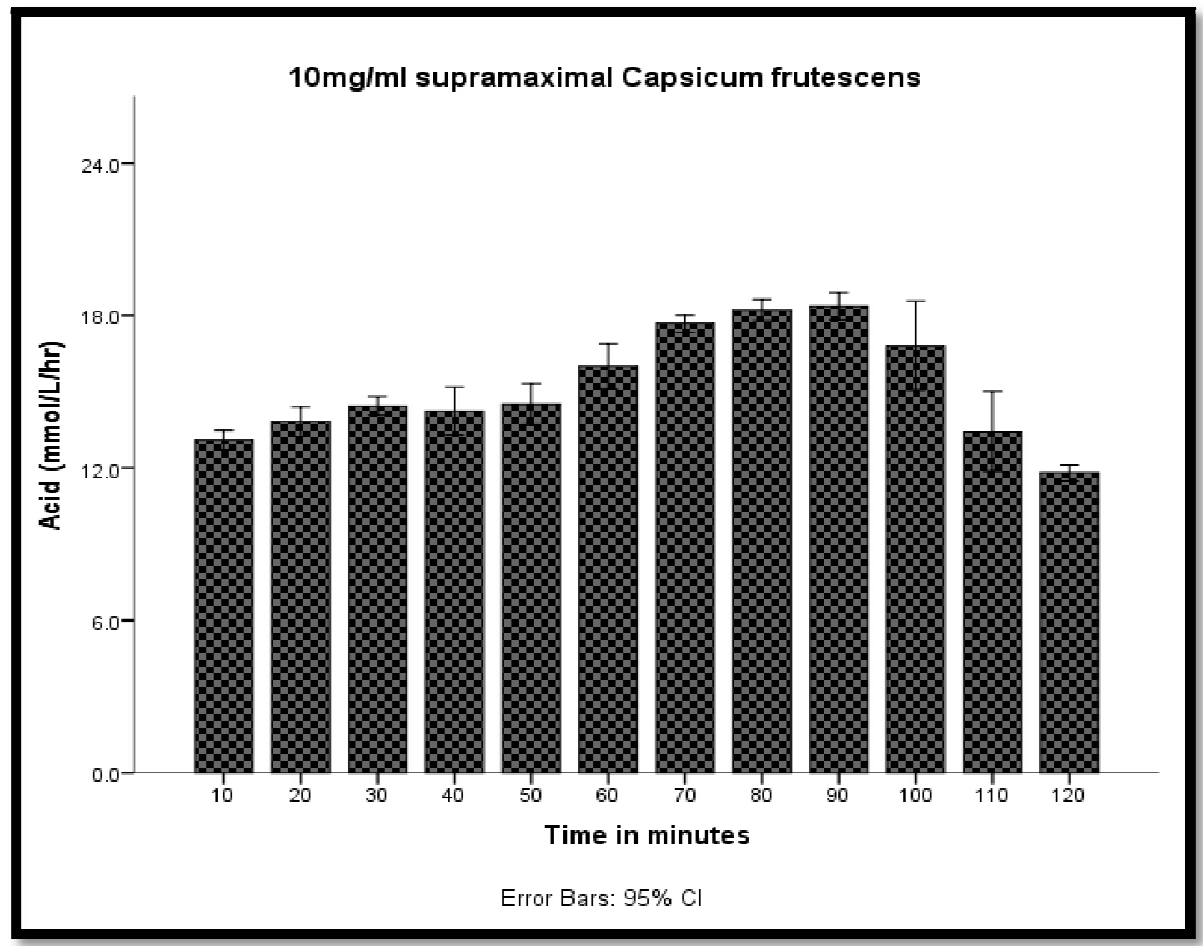

Figure 4 
Figure 4 shows the graph of administration of $10 \mathrm{mg}$ supramaximal dose of Capsicum frutescens. A peak response is observed at 70, 80 and 90 minutes with decline in acid secretory response at 100,110 and 120 minutes. This decline in acid secretory response is called tachyphylaxis.

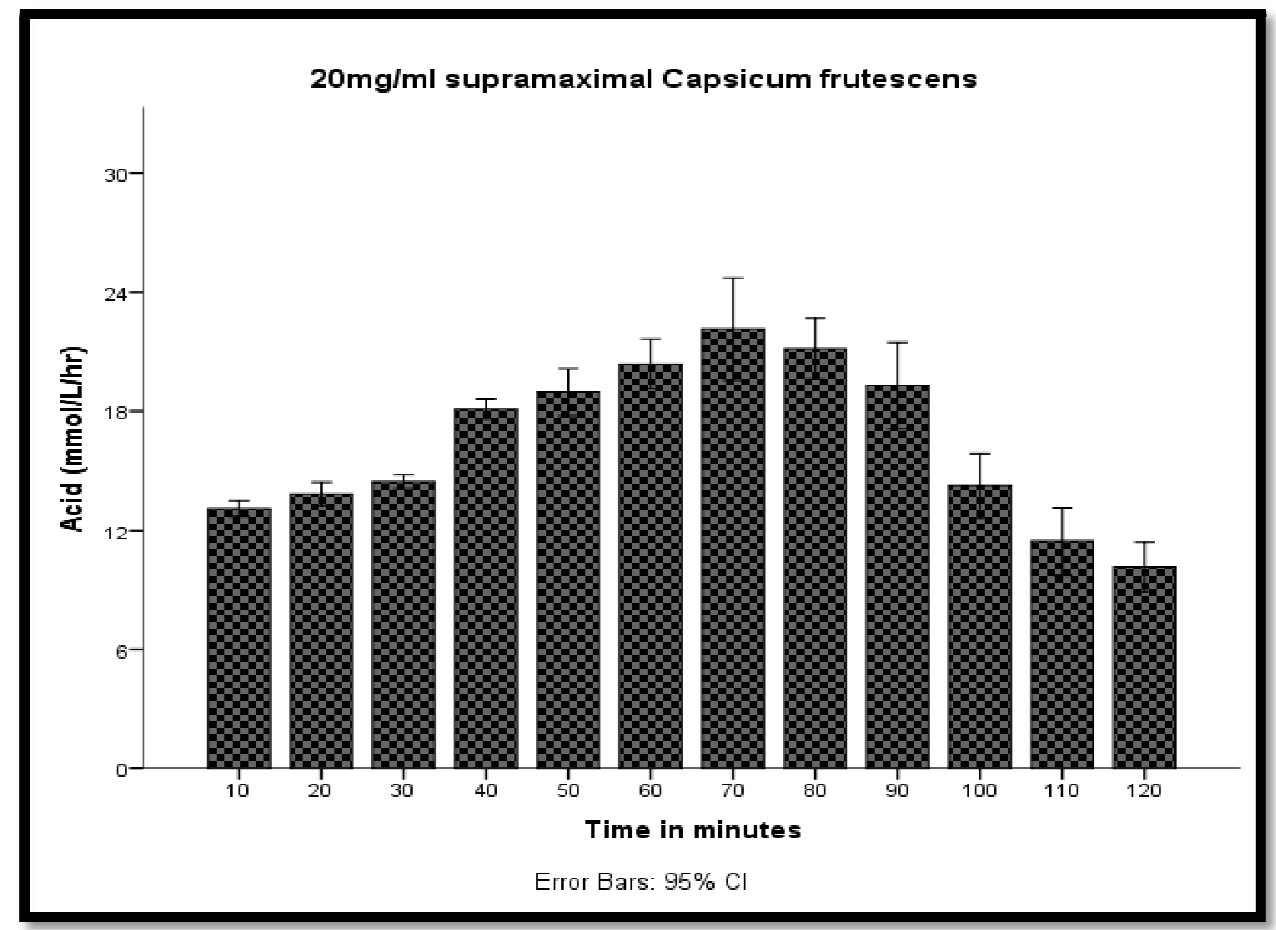

Figure 5

Figure 5- Graph showing the administration of 20mg supramaximal dose. A peak response occurred at 70 minutes, with decline in acid secretory response at 100, 110 and 120 minutes. This decline in acid secretory response is called tachyphylaxis.

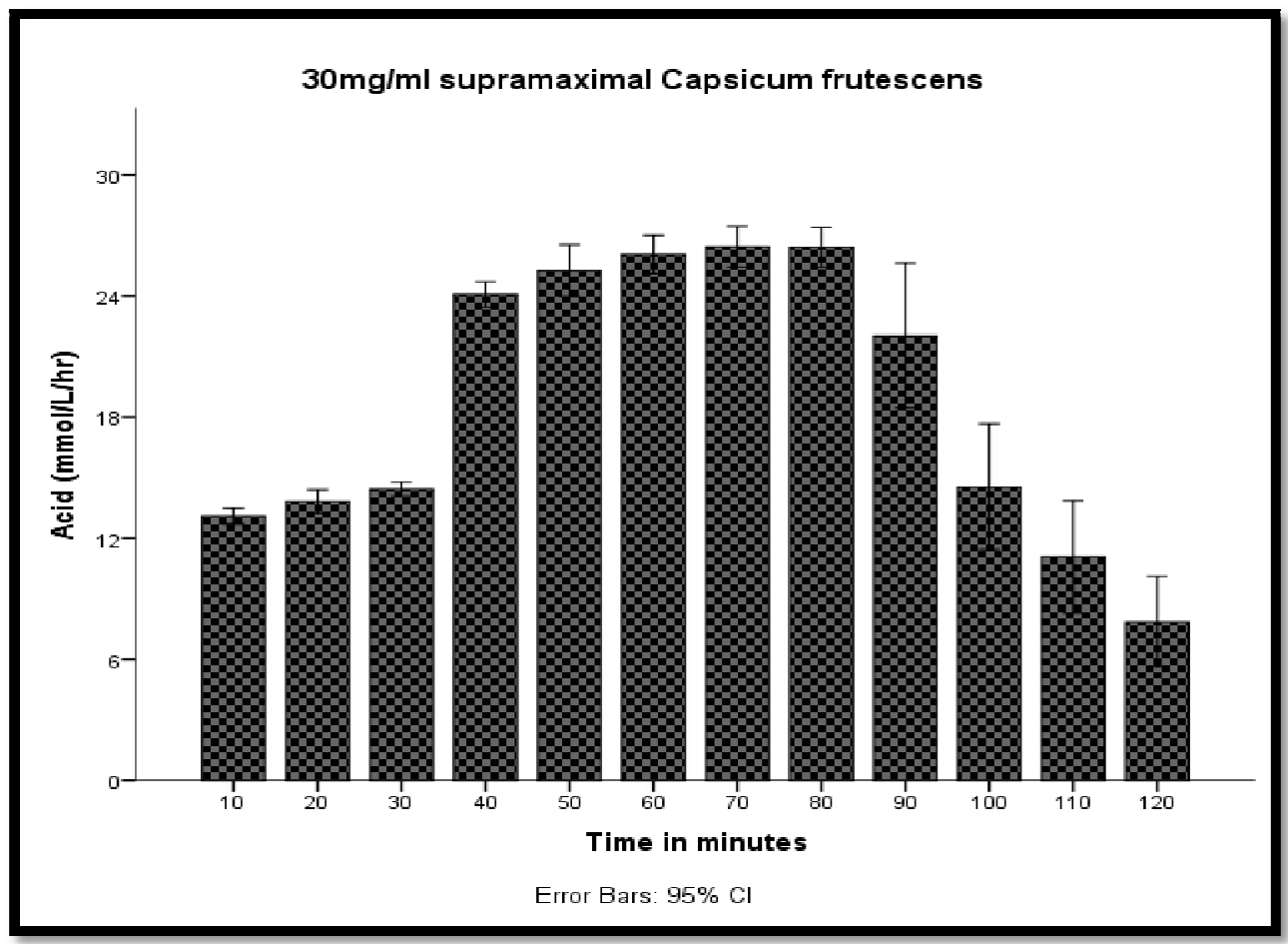

Figure 6 
Figure 6- Shows a graph of administration of 30mg supramaximal dose of Capsicum frutescens. A peak response is seen between 60 and 80 minutes, with decline in acid secretory response at 90, 100, 110 and 120 minutes. This decline in acid secretory response is called tachyphylaxis.

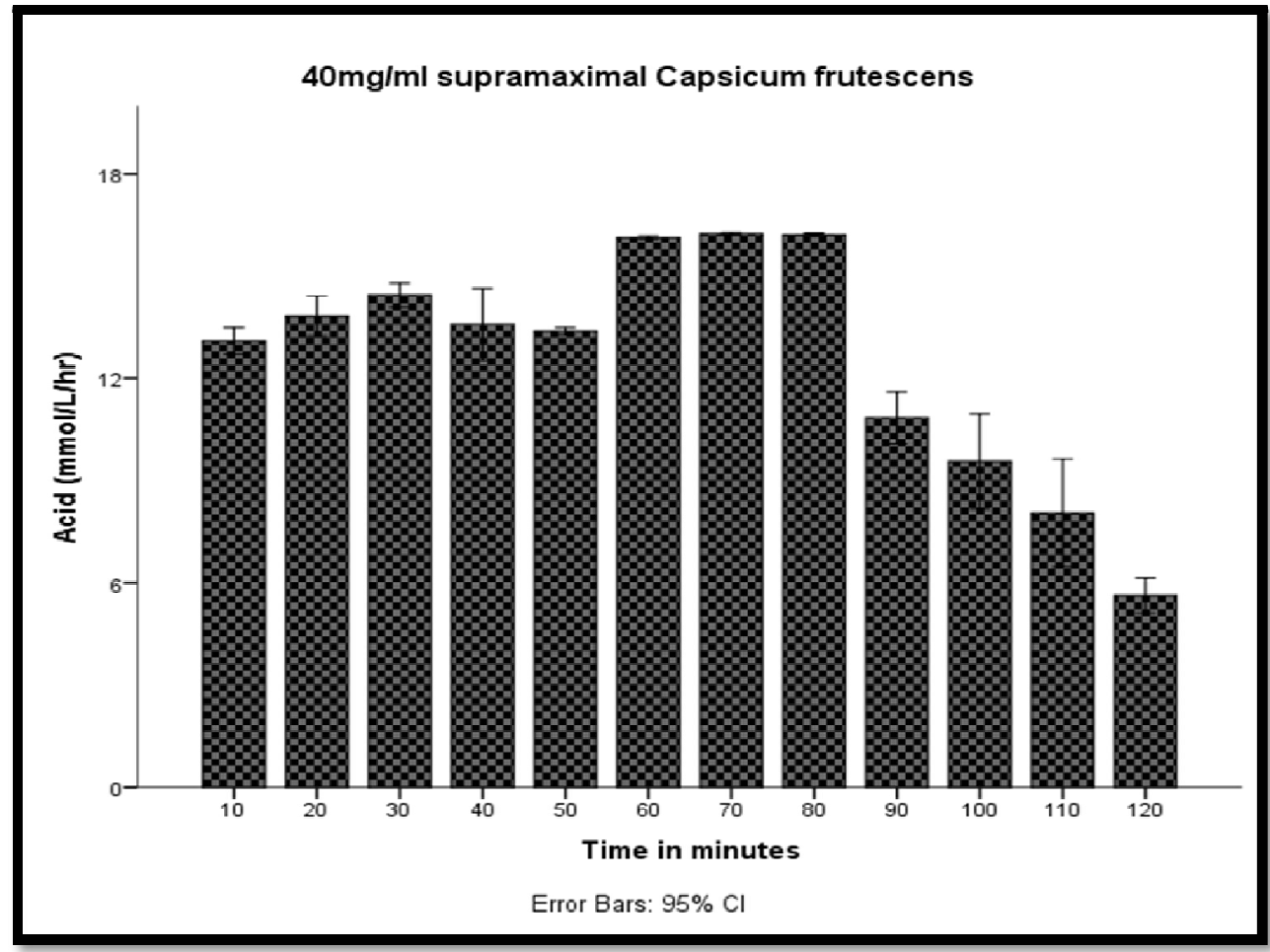

Figure 7

Figure 7- Shows a graph of administration of $40 \mathrm{mg}$ supramaximal dose of Capsicum frutescens. A peak response is seen between 60 and 80 minutes, with decline in acid secretory response at 90,100, 110 and 120 minutes. This decline in acid secretory response is called tachyphylaxis.

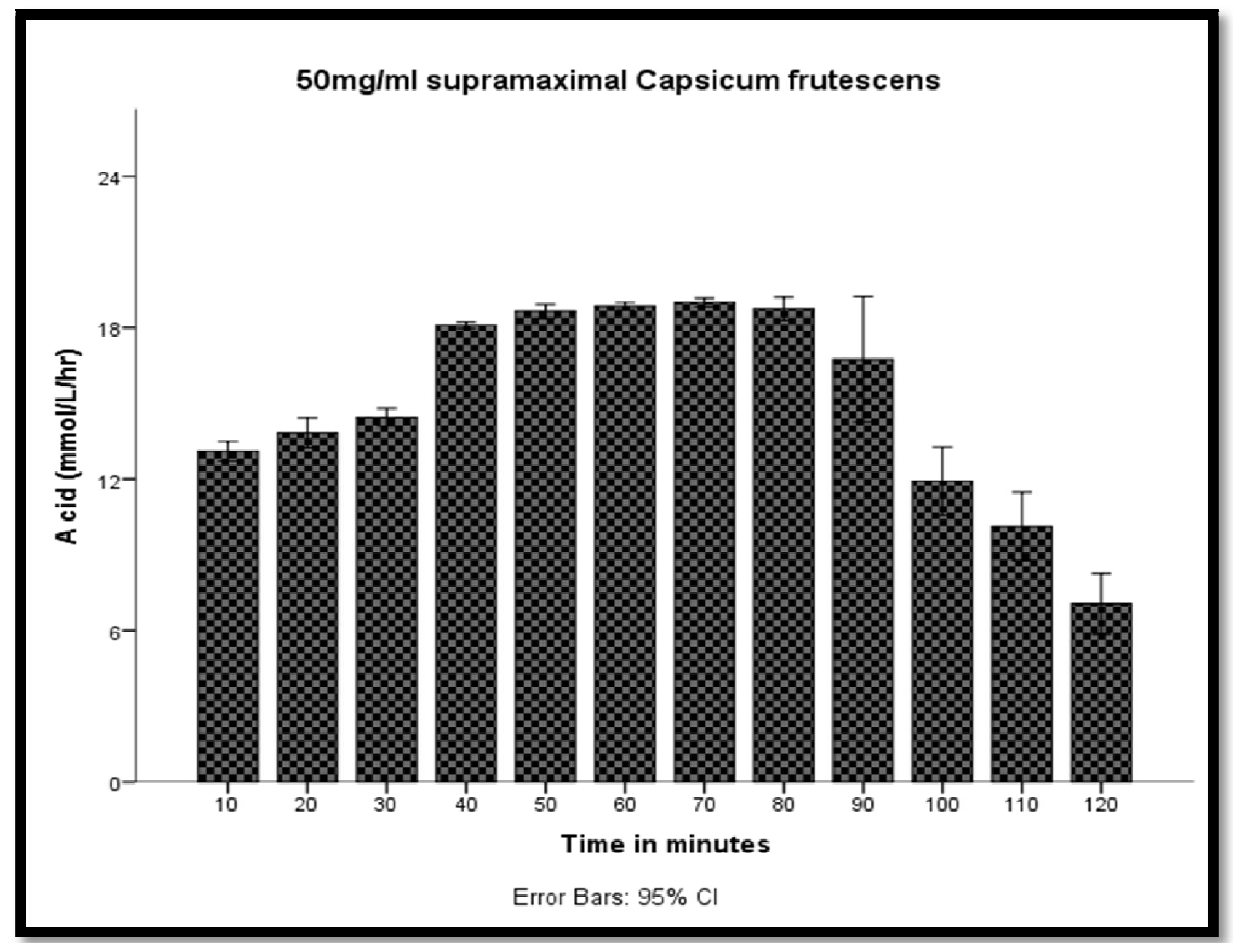

Figure 8 
Figure 8- Shows a graph of administration of 50mg supramaximal dose of Capsicum frutescens. A peak response is seen between 50 and 80 minutes, with decline in acid secretory response at 90, 100, 110 and 120 minutes. This decline in acid secretory response is called tachyphylaxis.

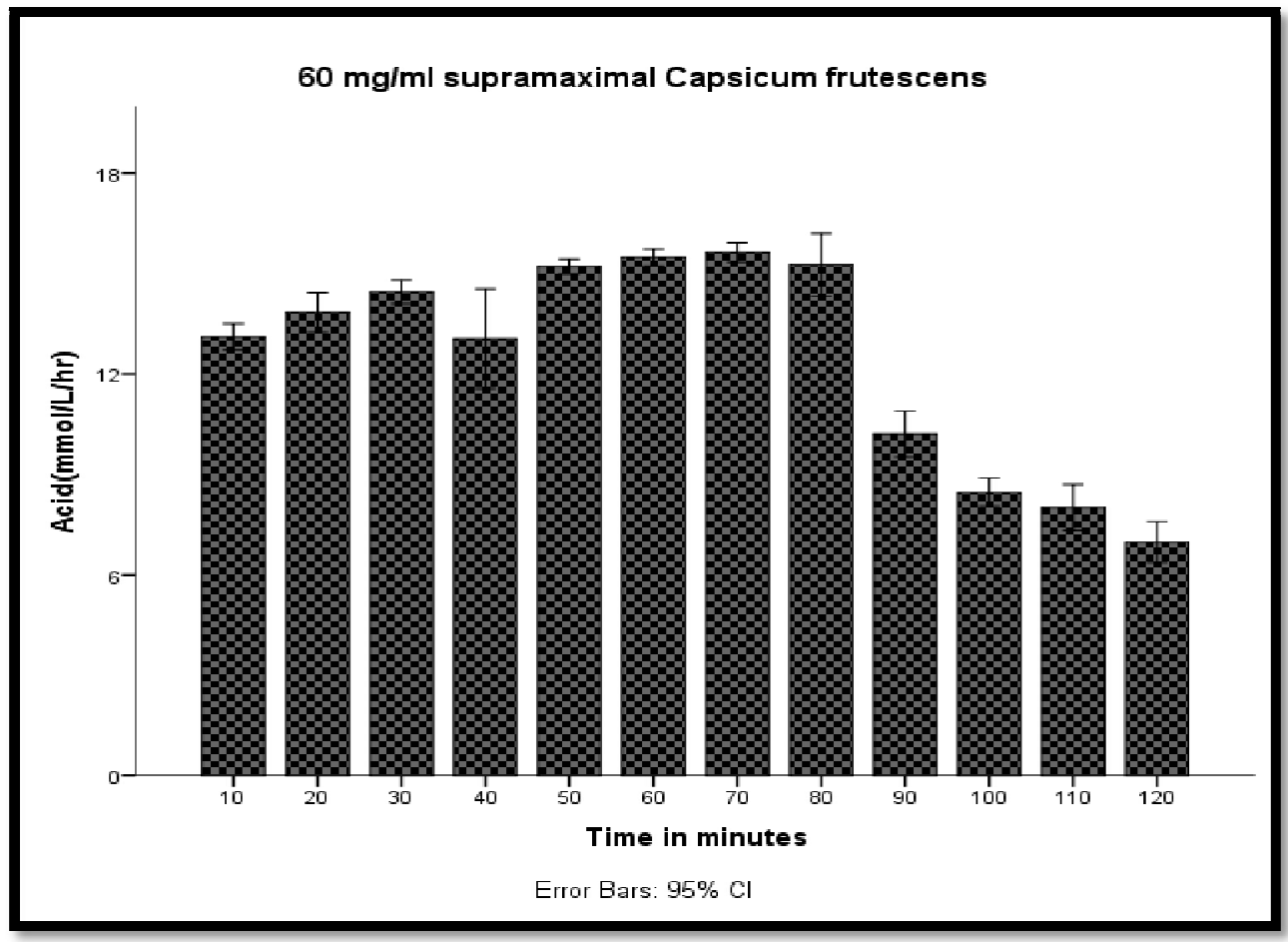

Figure 9

Figure 9- Shows a graph of administration of $60 \mathrm{mg}$ supramaximal dose of Capsicum frutescens. A peak response is seen between 50 and 80 minutes, with decline in acid secretory response at 90,100,110 and 120 minutes. This decline in acid secretory response is called tachyphylaxis.

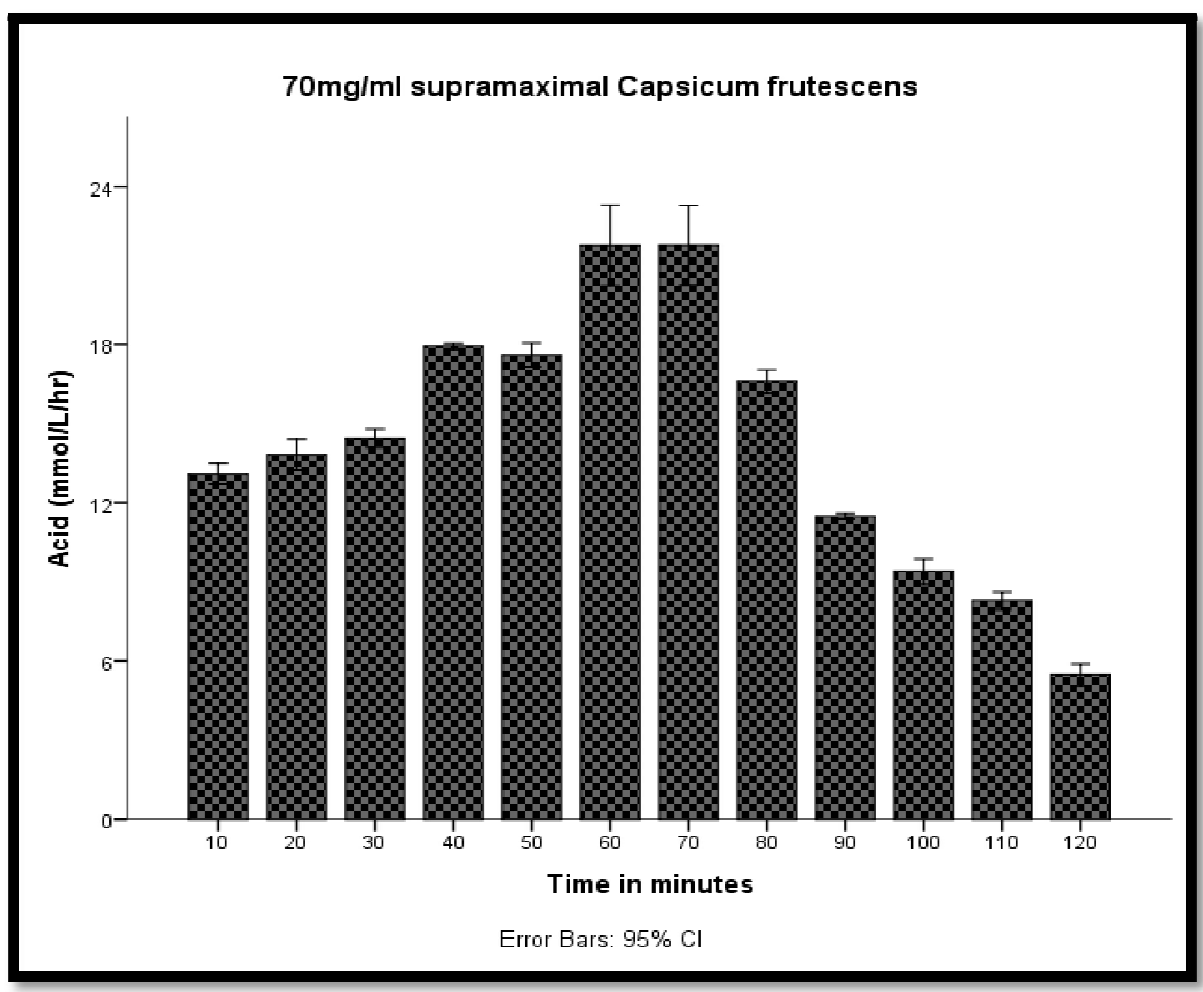

Figure10 
Figure 10- Shows a graph of administration of 70mg supramaximal dose of Capsicum frutescens. A peak response is seen between 60 and 70 minutes, with decline in acid secretory response at 80, 90, 100, 110 and 120 minutes. This decline in acid secretory response is called tachyphylaxis.

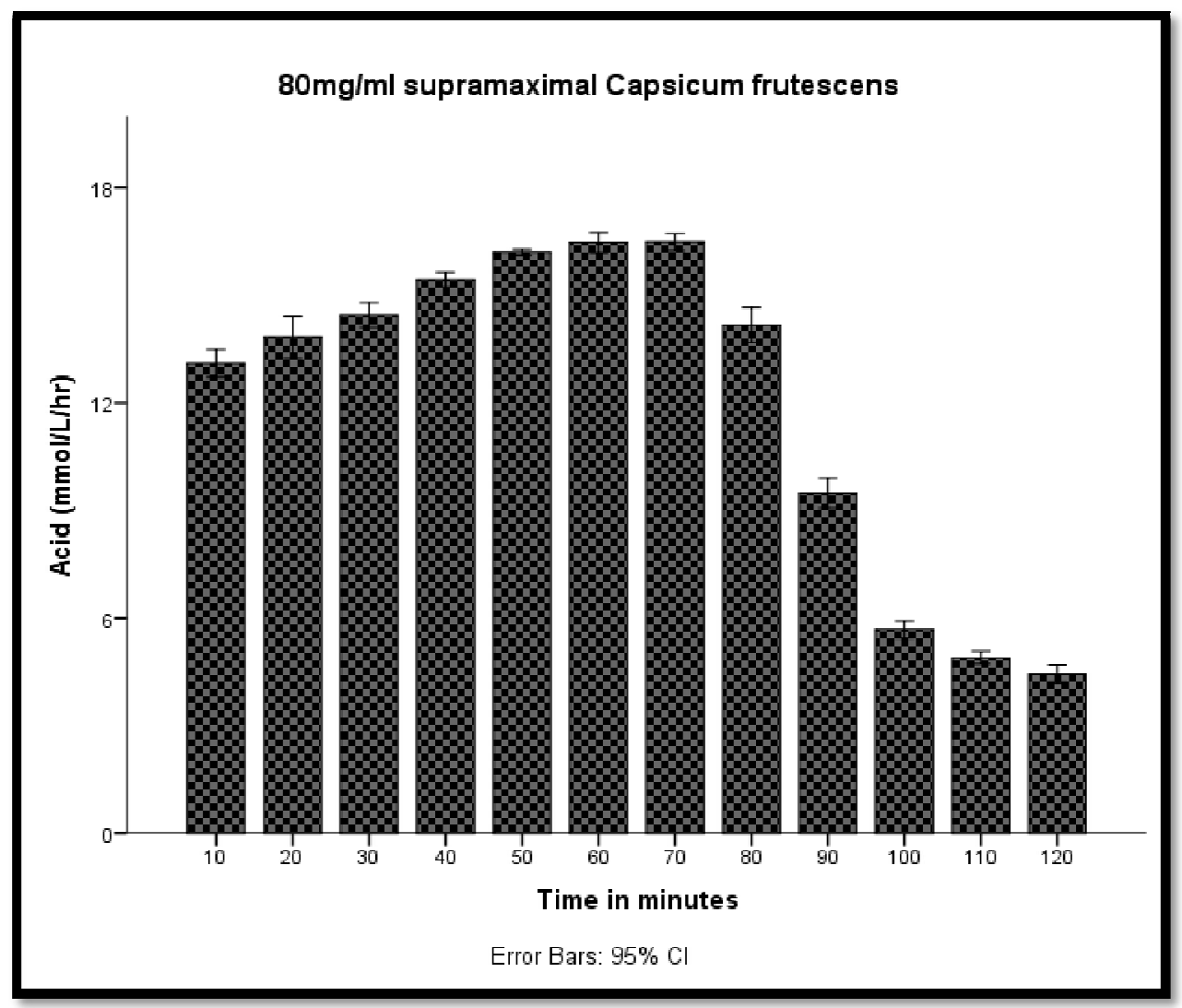

Figure 11

Figure 11- Shows a graph of administration of $80 \mathrm{mg}$ supramaximal dose of Capsicum frutescens. A peak response is seen between 50 and 70 minutes, with decline in acid secretory response at 80, 90, 100, 110 and 120 minutes.

There was statistically significant difference between BAO and the acid secretion at $60,70,80$ and 90 minutes $(\mathrm{p}<$ 0.01). Also, the difference between the peak acid output (PAO) and the acid secretions at the levels of decline at 90 to 120 of the different doses was statistically significant $(p<0.01)$.

\begin{tabular}{|l|l|l|l|l|l|}
\hline \multicolumn{7}{|c|}{ ANOVA } \\
\hline & $\begin{array}{l}\text { Sum of } \\
\text { Squares }\end{array}$ & df & Mean Square & F & Sig. \\
\hline Between Groups & 9.441 & 11 & .858 & 15.759 & .000 \\
\hline Within Groups & 4.575 & 84 & .054 & & \\
\hline Total & 14.016 & 95 & & & \\
\hline
\end{tabular}

Table 1: $10 \% \mathrm{LD}_{50}$ Capsicum Frutescens

Table 1- The table shows ANOVA for $10 \% \mathrm{LD}_{50}$ Capsicum frutescens. There is no statistical difference within group, however there was significant statistical difference $(\mathrm{p}<0.001)$ between groups. Similar ANOVA results were obtained for all the other doses studied.

\section{Discussion}

Hot peppers such as Capsicum frutescens contain capsaicin as the active principle. Capsaicin exerts it activity through the capsaicin-sensitive sensory afferent nerves. Capsaicin-sensitive afferent neurons play a central role in the neuronal mechanism of the stomach (Holzer,1998). These afferent neurons control several actions such as mucosal blood flow, secretion, motility and maintenance of the mucosal integrity of the stomach (Holzer and Sametz; 1986 Holzer, 1998; Takeuchi et al., 1991, 1992). Capsaicin has several actions, its effects on gastric acid secretion has been studied by a few researchers (Ibu et al., 1993, Akwaraset al., 2018). Some studies report that low-dose capsaicin can decrease gastric acid secretion while high-dose may increase gastric acid secretion (Ibu et al., 1993, Ericson et al., 2009, Akwaraset al., 2018) Red chili ingested 
daily over 3 weeks resulted in an increased secretion of gastrin, while a chili-rich diet lowered gastrin secretion (Ericson et al., 2009). Repeated exposure of the esophageal mucosa to red chili pepper sauce initially increased heartburn, but subsequently exerted an analgesic effect, (Bortolotti etal., 2002) and $2.5 \mathrm{~g}$ of red pepper daily over 5 weeks resulted in a decrease in the intensity of dyspepsia after 3 weeks. A mechanism of initial sensitization, followed by desensitization of gastric norciceptive Cfibers, has been suggested (Bortolotti et al., 2002). Also, Imatake et al., 2009 Capsaicin inhibited gastric acid output, and the mechanism underlying this effect appears to involve vagal nerve inactivation. So, the final effects of capsaicin depend on the dosage and timing.

Vanilloid receptor type 1, a nonselective cationic channel, has been recently cloned as the binding site of capsaicin (Caterina et al.,1997) and, more recently, has been shown to be one of the transient receptor potential (TRP) family of ion channels (Clapham et al., 2001). Although the TRP family is activated by a diverse range of stimuli, including depletion of intracellular $\mathrm{Ca}^{2+}$ stores (Caterina et al., 1997), the vanilloid receptor type 1 receptor remains the only channel activated by vanilloids such as capsaicin and is now known as TRPV1 (Gunthorpe et al., 2002). The difference in the effects of capsaicin on gastric acid secretion may be related with the location of vanilloid receptor subtype 1, dose of capsaicin, route of administration, and the release of some substances such as calcitonin gene-related peptide, neurokinin A, vasoactive intestinal peptide and substance $\mathrm{P}$ (Tan et al., 2009).

It is concluded that tachyphylaxis is exhibited by Capsicum frutescens stimulated gastric acid secretion in albino wistar rats. The tachypylaxis shown in this study may explain why people who take peppers in their diet repeatedly and at high doses eventually end up not having the expected increased acid secretory response.

\section{Conclusion and Recommendations}

- The results of the present study may be helpful to pharmaceutical manufacturing companies when they are doing their national formulary for the populace.

- Health education to give public awareness related to the findings in this research will be of importance for pepper consuming persons.

\section{References}

i. Alnaqueeb MA, Thompson M, Bordia T, and Ali M. (1996). Histopathological effects of garlic on liver and lungs of rats. Toxicol Lett. 85: 157-164.

ii. Bortollotti M, Coccia G, Grossi G, Miglioli M. (2002). The treatment of functional dyspepsia with red pepper. Ailment Pharmacol Ther, 16(6):1075-1082.

iii. Caterina MJ, Schumacher MA, Tominaga M, Rosen TA Levine JD, and Julius D. (1997). The capsaicin receptor; a heatactivated ion channel in the pain pathway. Nature (Lond) 389:816-824.

iv. Clapham DE, Runnels LW, and Strubing C (2001) The TRP ion channel family. NatRev Neurosci 2:387-396.

v. Ekwere MR, Udoh DE. (2016). Extraction and comparative analysis of moisture and capsaicin contents of capsicum peppers. J pain Relief 5:268.

vi. Ericson A, Nur EM, Petterson F, and Kechagias S. (2009). "The effects of capsaicin on gastric secretion in isolated human antral glands: before and after ingestion of red chilli” Dig Dis Sci., 54(3): 491-498.

vii. Green BG. (1996). Rapid recovery from capsaicin desensitization during recurrent stimulation. Pain.68:245-253.

viii. Ghosh MN and Schild HO. (1958). Continuous recording of gastric acid secretion in Rat. BritJ. Pharm 13: 54-61.

ix. Gunthorpe MJ, Benham CD, Randall A, and Davis JB (2002) The diversity in the vanilloid (TRPV) receptor family of ion channels. Trends Pharmacol Sci 23:183-191.

x. Holzer P and Sametz W (1986). Gastric mucosal protection against ulcerogenic factors in the rat mediated by capsaicin-sensitive afferent neurons. Gastroenterology 91:975-987.

xi. Holzer P (1998). Neural emergency system in the stomach. Gastroenterology 114: 823-839.

xii. Holzer P (2006). Efferent-like roles of afferent neurons in the gut: Blood flow regulation and tissue protection. Auton Neurosci 125: 70-75.

xvi. Holzer P.(2007a). Role of visceral afferent neurons in mucosal inflammation and defense. Curr Opin Pharmacol 7: 563-569.

xvii. Holzer P. (2007b). Taste receptors in the gastrointestinal tract. V. Acid sensing in the gastrointestinal tract Am J Physiol Gastrointest Liver Physiol 292: G699-705.

xviii. Ibu JO, Nwokediukko SC, Okpara E (1986). The nature of stimulation of gastric acid secretion by cola nitida using antimuscarinic drugs. Process West Soc Gastroent. 1:7-8.

xix. Ibu JO, Irozuru MN, Dakar DD (1993). Effects of Capsicum annum, Capsicum frutescens and Tamarindus indica (African peppers) on gastric acid secretion. Nig Med J. Vol 24(suppl): 9-12.

xx. Ibu JO. (1987). Synopsis of medical physiology. Manchester Amazon Press.

xxi. Imatake K, Matsui T, Moriyama M. (2009). The effect and mechanism of action of Capsaicin on gastric acid output. Journal of Gastroenterology 44(5):396-404.

xxii. Jara-Oseguera A, Simon SA, and Rosenbaum T. (2008) TRPV1: on the road to pain relief. Curr Mol Pharmacol 1: 255269. 
xxiii. Mc Namara FN, Randall A, Gunthorpe MJ. (2005). Effect of piperine, the pungent component of black pepper at the human vanilloid receptor 9 TRPV10. British journal of Pharmacology. 144;781-790.

xxiv. Saito A, Yamamoto M.(1996). Acute oral toxicity of capsaicin in mice and rats. J Toxicol Sci. 21(3):195-200.

xxv. Szallasi A, Blumberg PM. (1999). Vanilloid (capsaicin) receptors and mechanisms. Pharmacol. Rev. 51:159-212.

xxvi. Tan T, Zhang Q, Peng Y. (2009). Effects of capsaicin on gastric acid secretion and mechanisms involved. World Chinese Journal of Digestology 17(36):3699-3703.

xxvii. Takeuchi K, Matsumoto J, Ueshima K, and Okabe S (1991) Role of capsaicin sensitive afferent neurons in alkaline secretory response to luminal acid in the rat duodenum. Gastroenterology 101:954-961.

xxviii. Takeuchi K, Ueshima K, Matsumoto J, and Okabe S (1992). Role of capsaicin sensitive sensory nerves in acid-induced bicarbonate secretion in rat stomach. DigDig Sci 37:737-743. 